\title{
Ichthyofaunal diversity in Bachan Gad and Kakda streams of the Mid-himalayan Ganga river system of Garhwal in relation to stream gradient and distance
}

\author{
Yogendra Singh, Ashish K. Chowdhary and S.N. Bahuguna* \\ Department of Zoology and Biotechnology, P.B.70, HNB Garhwal University Srinagar-Garhwal-246174 \\ (Uttarakhand), INDIA \\ *Corresponding author. E-mail: profsnbahuguna @ rediffmail.com
}

Received: February 8, 2014; Revised received: May 4, 2014; Accepted: June 15, 2014

\begin{abstract}
The present study was carried out to investigate the comparative seasonal distribution and relative abundance of fish fauna of streams Bachan Gad of river Alaknanda and Kakda Gad of river Mandakini of Mid-himalayan Ganga river System. Total length of the Bachan Gad is $14.5 \mathrm{~km}$ from origin to the confluence at main river Alaknanda with an altitudinal variation from 605.94 to $1418.23 \mathrm{~m}$ (a.s.1), whereas, total length of the Kakda Gad is $15.5 \mathrm{~km}$. from origin to confluence at main river Mandakini with altitudinal variation from 984.50 to $1993.70 \mathrm{~m}$ (a.s.1). Total 23 species from Bachan Gad and 20 fish species were identified from Kakda Gad. The differences in the availability of fish-fauna were directly related to the nature of the profile and slope of tributaries; which affects the migration and breeding grounds of the fishes inhabited in the main river Alaknanda and Mandakini of Ganga river system. Variation in the availability of fishes has been recorded from different sites of the stream. In streams and rivers the changes take place along their length is directly related to the eco-physico-chemical nature (water depth, current, substratum etc). All these factors which change along the length of streams are also the factors which control the distribution of the various sections of the biotic fauna and flora.
\end{abstract}

Keywords: Bachan Gad, Hill-stream fish fauna, Kakda Gad, Relative abundance, Seasonal distribution

\section{INTRODUCTION}

Garhwal Himalaya is very rich by means of snow-fed rivers and tributaries. These rivers and tributaries have great diversities of the fish fauna. The Western Himalayan hill streams pose harsh living conditions to the fish communities because of varied topography, torrential water currents coupled with a variety of substratum. Positive correlations between biomass production and species abundance have been studied earlier (Nikolosky, 1978). The longitudinal replacement of fish species as noted by Hutchinson (1939), Burton and Odum (1945) were associated with specialized fish population of high altitudes, while Edds (1993) studied the fish assemblage on the basis of longitudinal zonation on Gandaki river in Nepal and observed the variation in fish species in different longitudinal zonation formed by the river. Singh and Kumar (2000) classified the fishes in different altitudinal zones, while Nautiyal (2001) also observed the altitudinal variation in the fishes and classify in different altitudinal zones in Garhwal Himalaya. Most of the small important streams of upper Ganga river system in Garhwal Himalaya remain unnoticed from fish diversity and river ecology view point. However some work has been conducted by Badola (1975),
Sharma (1984), Singh et al. (1987), Dobriyal and Kumar (1988), Bisht et al. (2009), Agarwal et al. (2011), Agarwal and Singh (2012) on the ecology and fish fauna of some of the tributaries of Ganga river system. Badola and Singh (1981a, 1981b) described that hill streams have low temperature, clear water, and high content of dissolved oxygen, neutral $\mathrm{pH}$, low carbon dioxide and fast current. Supporting factors are also responsible for the abundance and good distribution of fish fauna among these small hill stream tributaries. Therefore, in the present study an attempt had been made to study the comparative seasonal distribution and relative abundance of fish fauna of small hill-streams Bachan gad of River Alaknanda and Kakda Gad of river Mandakini from Garhwal Himalaya.

\section{MATERIALS AND METHODS}

The present research work has been conducted on Kakda Gad of river Mandakini and Bachan Gad of river Alaknanda in district Rudraprayag. From each tributary five sampling stations (sites) were selected for monthly sampling of physico-chemical parameters and collection of fishes for the taxonomical study as method given by APHA, 1995 were followed. Overall ten sampling sites spread over two tributaries viz. 
Bachan Gad and Kakda Gad were selected (Fig.1) The study was conducted during April 2009 to March 2012. Fish sampling was done monthly at all selected sites, up to a $2-5 \mathrm{~km}$ distance in each river, by use of Cast net, Gill net and other fishing methods. The mesh size of Cast net and Gill net were 2.0-3.0 cm and 2.0$10.0 \mathrm{~cm}$, respectively. The fish records from local fishermen were also regularly noted at each site.

Site of Bachan Gad: Bachan Gad is a Tributary of river Alaknanda in Rudraprayag district of Uttarakhand (Fig. 1a). The origin point of this tributary is at an altitude of $2500 \mathrm{~m}(8202.10 \mathrm{ft})$, from the Lirkhal Dhar (hills) situated longitudinally $30^{\circ} 10^{\prime} \quad 03.50$ ", North and latitudinal $78^{\circ} 51^{\prime} 15.05 "$ East in Rudraprayag district of Uttarakhand. Confluence with Alaknanda of this Bachan Gad is at altitude of $650 \mathrm{~m}$ $(2132.5 \mathrm{ft})$ situated longitudinally $30^{\circ} 14^{\prime} 35.8^{\prime} \mathrm{N}$ and latitudinal $78^{0} 51^{\prime} 45.03$ " E. It is a small spring fed tributary and have a good source of fish diversity in. In this tributary five sites were selected viz. S1.Navgaon (605.94m a.s.1), S2.Khankra (733.35m a.s.1), S3.Sipry (870.81m a.s.1), S4.Kandai (1031.75m a.s.1) and S5.Pata (1418.23m a.s.1.). Each sampling site was located 3 to $4 \mathrm{~km}$. from each other and the total length of the Gad was $14.5 \mathrm{~km}$. The drainage pattern varied from dendritic to trellis type along the moderately sloping and flat or gently sloping ground, respectively. Site of Kakda Gad: Mandakini is an important parental stream of Alaknanda (Fig. 1b). The diverse and endemic freshwater fish fauna in river Mandakini are supported by many small tributaries. Kakda Gad is one of the tributaries of river Mandakini which is approximately $15.5 \mathrm{~km}$ long. Geographically, this valley is situated between the latitudes $30^{\circ} 26^{\prime} 55^{\prime \prime}$ to $30^{\circ} 31^{\prime} 50^{\prime \prime} \mathrm{N}$ and longitudes $79^{0} 5^{\prime} 50^{\prime \prime}$ to $79^{0} 13^{\prime} 50^{\prime \prime} \mathrm{E}$. The origin point of the tributary is at $3680 \mathrm{~m}(12073.5$ ft.) from the Tungnath Hills (Chandara Shila) situated longitudinally $30^{\circ} 29^{\prime} 49.40^{\prime}$ N $\mathrm{N}$ and latitudinally $79^{\circ} 12$ ' 15.84 " E. Confluence with Mandakini of this stream is at Kund (near Gupta Kashi, Kedar Nath road) at a longitude of $30^{\circ} 29^{\prime} 26.35 " \mathrm{~N}$ and latitude $79^{\circ}$ 05 '02.18" E. Kakda gad catchment is approximately of $59 \mathrm{~km}^{2}$. The confluence point of the tributary is at 960 m. (3149.6 ft). This tributary is an important source of fish diversity of the Mandakini river. Kakda Gad is a small spring fed tributary where five sites were selected viz. S1.Kund (984.504m a.s.1.), S2.Mastura (1142.09m a.s.1.), S3.Silgut (1246.63m a.s.1.), S4. Makumath (1457.25m a.s.1.) and S5. Pingalpani (1993.70 ma.s.1.).Each sampling site was located 3 to $4 \mathrm{~km}$. from each other and the total length of the Gad was $15.5 \mathrm{~km}$. The drainage pattern varied from dendritic to trellis type along the moderately slopping or gently sloping ground, respectively.

\section{RESULTS}

The relative abundance and seasonal distribution of the fish fauna on the basis of variation in altitude and longitude in these two tributaries has been shown in tables 1 and 2. Overall 24 species belonging to 2 orders, 3 families, 5 sub-families and 9 genera were recorded from these two tributaries viz. Bachan Gad and Kakda Gad. Mostly fish species were common in these tributaries, while the difference was noted in quantity where some species were abundant and some were absent. The detailed study of each tributary is as follows:

Bachan Gad: Total 23 species; belonging to 2 orders, 3 families, 5 sub-families and 9 genera of the fish speceis were identified from Bachan Gad. Variation in the availability of fishes has been recorded from each site of this stream (Table 1).

During the study period, the highest diversity was recorded during monsoon season. The most abundant species recorded from Bachan Gad was Schizothorax sp., followed by Barilius, Noemacheilus, and Pseudecheneis in all the seasons, while Schizothoraichthys progastus was recorded rarely from site S-1 (Navgaon) and S-2 (Khankra) only in monsoon season. It was noticed that $N$. stariatus was totally absent from this stream. Maximum fish fauna was recorded during monsoon season due to migratory behavior of some fishes and change in physicochemical nature (temperature, dissolved oxygen (DO), water velocity, $\mathrm{pH}$ and turbidity). Some other factors like long stream length as well as stream geometry (viz. stream shape, nature of stream profile, average gradient, slope and circularity index, etc.) affected the availability of fishes.

Kakda Gad: A total number of 20 species were identified from this stream. Seasonal distribution and availability of fishes from each site is given in table 2 .

Tor putitora, T. tor, S. progastus and N. gangeticus all together were found absent from Kakda Gad during the study period (2009-12). Barilius bendelisis was the most abundant species, followed by Pseudecheneis sulcatus and Noemacheilus sp. and Schizothorax sp., respectively. The maximum fish fauna was recorded in monsoon season during the study period.

\section{DISCUSSION}

The present study is based on altitudinal and longitudinal basis. Geographically, these streams rise from the water divided zone of Alaknanda and Mandakini Rivers are located in the lower Alaknanda basin. These streams are of different orders, i.e. fourth order (Bachan Gad) and fifth order (Kakda Gad) and with their different profile nature.

During the study period, snow trout (S. progastus) and mahseer (Tor putitora, Tor tor) have been observed in Bachan Gad during the monsoon season. This is due to the breeding migration and availability of basic fish food items (macro-zoobenthos, algae, diatoms and zoo -planktons). The highest densities of the basic food items for the fishes are available viz. diatoms, protozoans, algae and macro-zoobenthos from Bachan, 
Yogendra Singh et al. / J. Appl. \& Nat. Sci. 6 (1): 298-303 (2014)

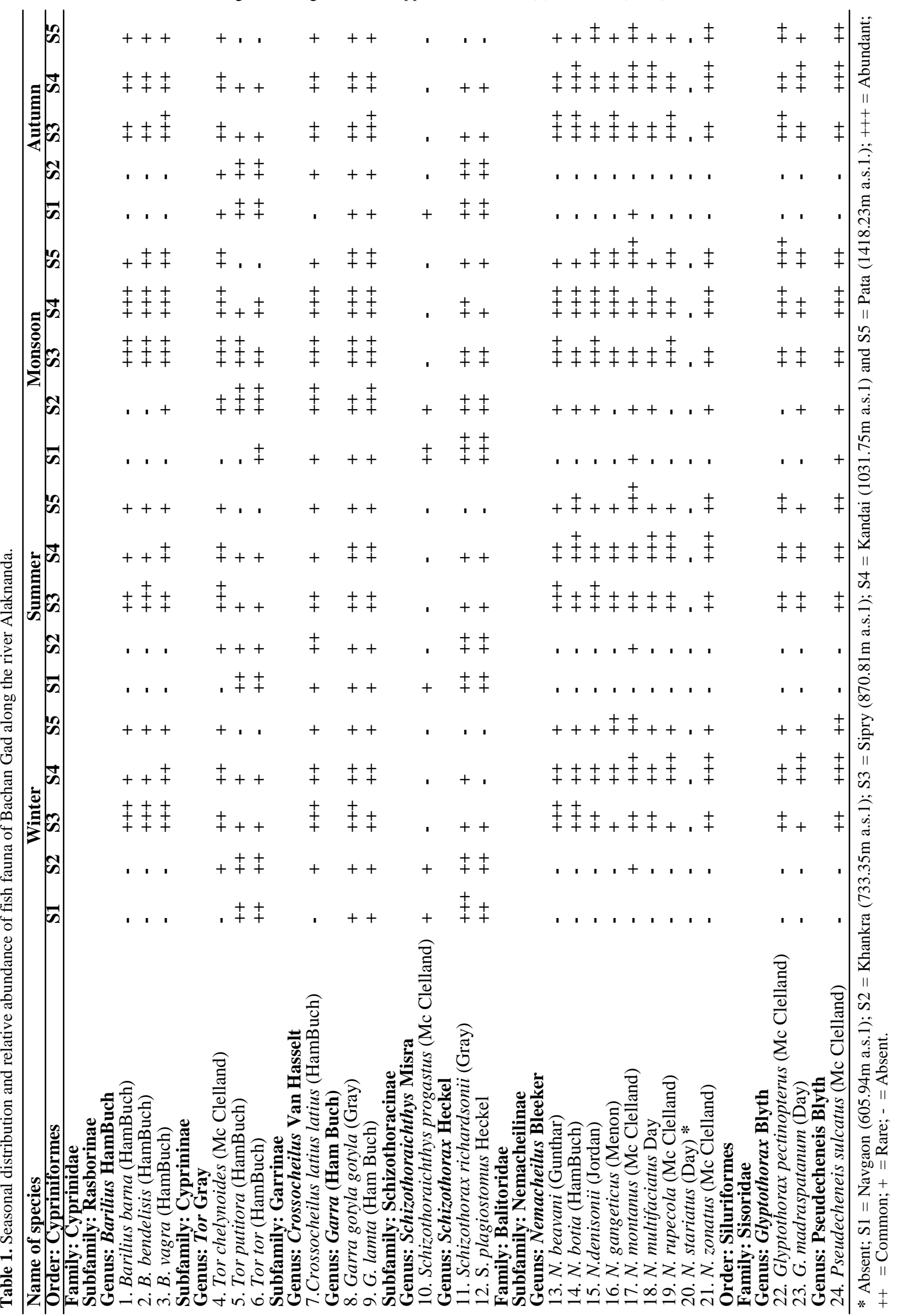




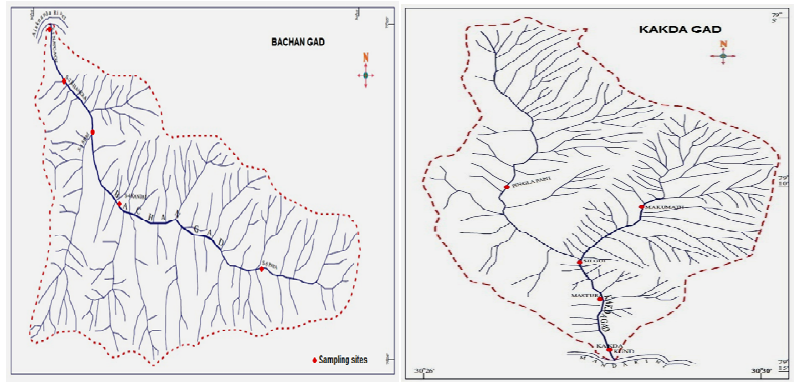

Fig.1. Location map of study area: a) Bachan Gad stream of river Alaknanda; b) Kakda Gad stream of river Mandakini of Ganga river system in district Rudraprayag (Garhwal).

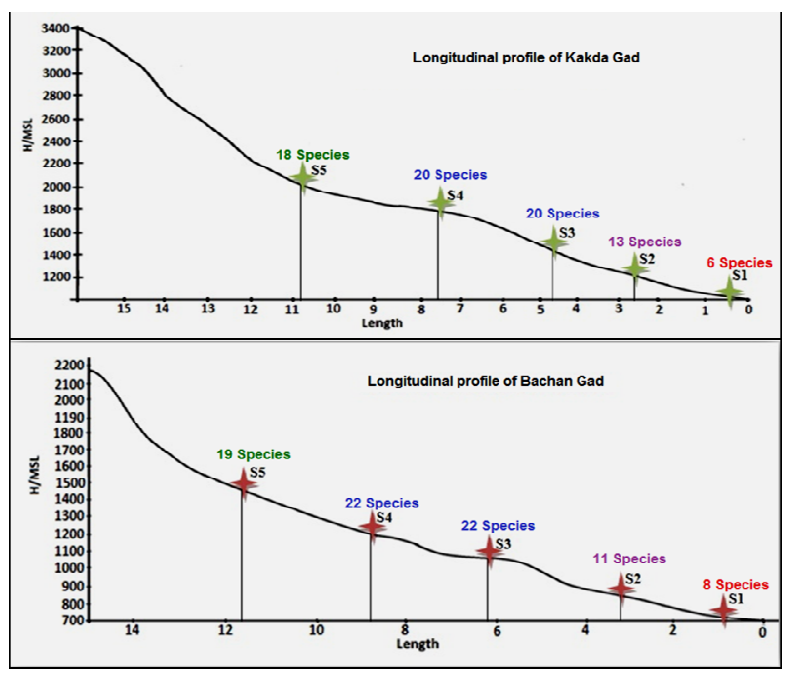

Fig.2. Longitudinal profile of streams illustrating species distribution.

which attract the good variety of fishes towards these tributaries. Similar opinion has also been given by Singh and Kumar (2000).

In streams and rivers, the changes taking place along their length are directly related to the physico-chemical nature, water depth, water current velocity, sedimentation of bottom and their turbidity. All these factors which change along the length of streams are also the factors, which control the distribution of the various sections of the biotic fauna and flora (Bahuguna and Badoni, 2002). The running water velocity is directly related to the biota zonation (Hynes, 1970). Such types of studies on running water revealed the reported existence of a zonal distribution of animals by many workers (Steinmann, 1907; Shelford, 1911; Thienemann, 1912 and Illies, 1963). In Western Europe, the fish classification was given on the basis of zones (Huet, 1959). Basically distinguished four zones were named after characteristics fishes; trout (Salmo), grayling (Thymallus), barbel (Barbus) and bream (Abramis), usually followed one another to the down order of the river (Huet, 1959). Huet has also shown that there was a fairly clear relationship between the slope of the stream and the fish zone that it harbored, and this slope decreased for a given zone the wider the stream. In the present study the morphometry has been recorded of these two streams. Slopes in degree of each stream were recorded for. Bachan Gad as $7.31^{\circ}$, and for Kakda Gad as $10.23^{0}$.

The difference in the availability of the fishes was recorded from all these tributaries due to their different sloping nature. Among these, maximum fish fauna was recorded from Bachan Gad (low gradient records); while the minimum fish fauna was recorded in Kakda Gad (high gradient records). The difference in the availability of fish fauna was directly related to the nature of profile and the slope of these tributaries, which affects the migration and breeding grounds of the fishes inhabited in the main river Alaknanda and Mandakini. The same has been noticed in other parts of the Uttarakhand river system (Uniyal, 2003).

The Substratum is the major factor, which influence the distribution and abundance of fish fauna (Bisht $e t$ al., 2009). These two tributaries possess rocky substratum with big boulders and pebbles, which forms the most favorable breeding grounds for the fishes, especially for Barilius Tor, Schizothorax, Glyptothorax sp, etc. Developing, hatchlings, hiding in crevices of rocks, stones and gravel, react differently to the current and turbidity of water (Shrestha, 1993; Uniyal, 2003).

River length is an important factor which affects the fish habitat of the study area in gradient of the stream. Higher gradient showed the less amount of fish fauna. In Kakda Gad found a high gradient, the stream $\mathrm{g}$ radient gradually rose towards the source, which showed 0.175484 gradient. Therefore, low quantity of fishes was observed in this stream. Besides, the stream gradient of Bachan Gad was found to be low as 0.127586 and therefore, the fishes were found in higher quantity of this stream.

Fast current and breeding season of these fishes force them for upward and downward migration too. Amount of water is also responsible for variation in distribution, because the amount of water affects the valley length and valley width. The fishes move in higher quantity in a narrow stream valley of these tributaries, rather than the wider valley of rivers Alaknanda, and Mandakini. Thus, stream geometry also plays a significant role to determine the fish habitat, fish breeding ground and fish migration along the stream. Longer stream length increases the abundance of fauna. Fish communities change along the length of rivers. Similar observations have been reported by Kleerekoper (1955), Oliff (1960), Chacko and Ganpati (1952) and Allen (1960).

Overall the variation in seasonal distribution and relative abundance of fish fauna is directly related to changes in physico-chemical nature, variation in altitude and longitude, channel course and water discharge, eco-morphological adaptive organs of the fishes.

In the present study, minimum fish species were found at $\mathrm{S} 1$ and $\mathrm{S} 2$ in all the seasons and in both the 
tributaries. While, maximum species were found at S3 and S4, and again, it decreased at S5. The reason behind less diversity of fish fauna near S1 and S2 may be because that these sites are near the confluence of the tributaries to the main river. The confluence being most affected by the human activities poses a danger and unfavorable zone for the fish fauna for their survival.

It was concluded that the regulation of a river by means of a dam, barrage or weir, triggers dramatic changes in the environment affects the biotic communities including fish. The fish fauna is directly related to water quality, habitat, and river regulation, etc. Among the most widespread and drastic of disturbances, the important ones are the damming of rivers for hydropower generation, flood control, recreational uses etc, of which former one is being most common phenomenon in Himalaya. Attention is, therefore, drawn towards judicious and thoughtful management of valuable resources in order to preserve the diversity of the fish fauna.

\section{REFERENCES}

Agarwal, N.K. and Singh, G. (2012). Documentation of fishes and physico-chemical characters of a stream Indrawati- a spring fed tributary of river Bhagirathi at Uttarkashi (Central Himalaya, Garhwal). Environment Conservation Journal, 13(3): 117-124.

Agarwal, N.K., Singh, G. and Singh, H. (2011). Present status of ichthyofaunal diversity of Garhwal Himalayan river Bhilangana and its tributaries with reference to changing environment. Environment Conservation Journal, 12(3):101-108

Allen, K.R. (1960). Freshwater fauna of Wellington. Science in Wellington, Roy. Soc. N. Z. Handbook. pp. 23- 4 337, 445.

APHA (1995). Standard methods for Examination of water and wastewater, $19^{\text {th }}$ Ed. American public Health Association, Washington, D.C. pp.1134

Badola, S.P. (1975). Fish fauna of Garhwal hills, part II (Pauri Garhwal-U.P.). Ind. J. Zoot., 16 (1): 57-70.

Badola, S.P. and Singh, H.R. (1981a). Fish and fisheries of the river Alaknanda. Proc. Nat. Acad. Sci. India, B 51: 133-142.

Badola, S.P. and Singh, H.R. (1981b). Hydrobiology of the river Alaknanda of Garhwal Himalaya. Indian J. Ecol. 8:269-276.

Bahuguna, S.N. and Badoni, A.K. (2002). Qualitative and quantitative productivity of fish food from three important tributaries of river Alaknanda. In: Him. J. Env. Zool, 16 (2): 215-222.

Bisht, B., Badoni, A. K. and Bahuguna, S.N. (2009). Seasonal Distribution and Relative Abundance of Fish Fauna of a Small Hill-Stream Dangchaura (Takoli) Gad, along with River Alaknanda. Our Nature, 7:182-186.

Burton, G.W. and Odum E.P. (1945). The distribution of Stream fishes in vicinity of Mountain Lake, Virginia. Ecology, 26: 182-184.

Chacko, P.I. and Ganpati, S.V. (1952). Hydrobiological survey of the Suruli River in the Highways, Madurai district, India, to determining its suitability for the introduction of the rainbow trout. Arch. Hydrobiol. 46: 128-41. 324-391.

Dobriyal, A.K. and Kumar, N. (1988). Fish and fisheries of the river Mandakini. In: R.D. Khulbe (Ed.), Prespectives in Aquatic Biology (pp 37-340). Papyrus: Publication House, Delhi.

Edds, D.R. (1993). Fish assemblage structure and Environmental correlates in Nepal's Gandaki River. Copiea, 1: 48-60.

Huet, M. (1959). Profile and biology of Western European Streams as related to fish management. Trans. Am. Fish. Soc. 88: 155-163, 383-384.

Hutchinson, G.E. (1939). Ecological observation of the fishes of Kashmir and Indian Tibet. Ecol. Mangos. 9:145-182.

Hynes, H.B.N. (1970). The ecology of running waters. Liverpool University Press, Liverpool, pp.555.

Illies, J. (1963). Revision der Sudamerikanischen Gripopterygidae (Plecoptera). Milt. Schweiz. Z. Hydrol. 24: 433-435, 392.

Kleerekoper, H. (1955). Limnological observations in northeastern Rio Grande do Sul, Brazil. Archiv für Hydrobiologie 50 (3/4): 553-567.

Nautiyal, P. (2001). Ichthyofauna, In: Garhwal Himalaya, Nature Culture and Society (O. P. Kandari and O. P. Gusain Ed.) pp. 191-197. Transmedia Publication, Srinagar Garhwal.

Nikolosky, G. V. (1978). The ecology of fishes. T.F.H. publications USA, pp: 352.

Oliff, W.D. (1960). Hydrobiological studies on the Tugela river system. Part I. the main Tugela River. Hydrobiologia, 16, 281-385.

Sharma, R.C. (1984). Icthyofauna of the snowfed river Bhagirathi of Garhwal Himalaya. Utter Pradesh J. Zool., 4(2): 208-212.

Shelford, V.E. (1911). Ecological succession I. Stream fishes and the method of physiographic analysis. Bio. Bull. Mar. Biol. Lab; Woods Hole, 21: 9-35, 383, 385.

Shrestha, T.K. (1993). Chronology of early development and life history of the golden mahseer in the intergravel environment of the Himalayan streams in Nepal. Advances in Limnology (H.R. Singh Ed.). Narendra Pub. House, Delhi; pp. 253-270.

Singh, H.R., Badola, S.P. and Dobriyal, A.K. (1987). Geographical distribution list of Icthyofauna of Garhwal Himalaya with some new records. J. Bombay Nat. Hist. Soc., 84(1): 126-132.

Singh, H.R. and Kumar, N. (2000). Some aspects of ecology of hillstreams. Stream morphology, zonation, characteristics, and adaptive features of ichthyofauna in Garhwal Himalaya. Modern Trends In Fish Biology Research (Datta Munshi, J.S., Ed.)., Narendra Publishing House, Delhi. pp.1-18.

Steinmann, P. (1907). Die Tierwelt der Gerbirgsbache. Eine faunistisch biologische studie. Annls Biol. lacustre, 2: 30-150-, vii, 122, 383, 390.

Thienemann, A. (1912). Der Bergbach des Sauerland. Int. Revue. ges. Hydrobiol. Hydrogr. Suppl. 4(2)I. 125 pp. 204, 383, 387, 390, 400, 411.

Uniyal, D. P. (2003). Eco-taxonomical studies of Ichthyofauna of the Amlawa and Asan rivers of Western Doon Valley. D. Phil Thesis Submitted, H. N. B. Garhwal University, Srinagar Garhwal. 